Acta Universitatis Wratislaviensis • No 3982

Literatura i Kultura Popularna XXV, Wrocław 2019

https://doi.org/10.19195/0867-7441.25.8

Anita Has-Tokarz

ORCID: 0000-0002-0552-3914

Uniwersytet Marii Curie-Skłodowskiej w Lublinie

\title{
Przyjemność (z) konsumowania... Książki kucharskie jako element systemów rozrywki dla dzieci (konteksty kultury konsumpcyjnej i medialnej)
}

Słowa kluczowe: książka kucharska dla dzieci, rynek mediów dla dzieci, rynek książki dla dzieci, marka dziecięca, system rozrywki dla dzieci, Walt Disney, kultura kulinarna, konsumeryzm dziecięcy

Keywords: cookbooks for children, the media market for children, the book market for children, children's brand, children's entertainment system, Walt Disney, culinary culture, child consumerism

\section{Książka kucharska dla dzieci jako zjawisko kultury popularnej}

Obserwując zjawiska współczesnej popkultury, trudno nie zauważyć rozwoju trendów i mód, wyrażających społeczne zainteresowanie sferą kuchni i żywienia. Skoncentrowanie uwagi na tych właśnie aspektach życia dostrzegły mass media, odpowiadając na społeczne zapotrzebowania wyspecjalizowaną ofertą w zakresie kulinariów i gotowania. Ekspansywnie rozwijają się takie segmenty rynku mediów, jak: prasa poświęcona gastronomii, literatura kulinarna, gatunek kina zwany food film, telewizyjne pasma i programy dotyczące kuchni, audycje radiowe o gotowaniu, internetowe poradniki kucharskie, blogi i vlogi o tematyce kuchennej, aplikacje kucharskie na urządzenia mobilne typu smartfon czy iPad, streaming kulinarny itp. Kulinarny „Zwrot tematyczny” w mediach wiąże się z przemianami społeczno-kulturowymi i pojawieniem się stylu życia tak zwanej 
nowej klasy średniej, dla której konsumpcja (w tym gotowanie i jedzenie) stała się jedną z istotnych strategii budowania tożsamości ${ }^{1}$.

Niewątpliwie zainteresowanie tematyką kuchni i stołu znamionuje współczesną „podkulturę dziecięcą”, by użyć określenia Jerzego Cieślikowskiego². Zdaniem wielu badaczy jest to wyraz postępującej komercjalizacji dzieciństwa ${ }^{3}$. W telewizjach na całym świecie powstają adresowane do najmłodszych programy o gotowaniu, w których udział biorą mali kucharze. Wiele takich formatów wyprodukowały krajowe stacje telewizyjne. Są to między innymi Kuchcikowo - gotowanie na ekranie (TVP1), Deserownia (teleTOON+), Little Chef (Kuchnia+), licencyjny Little Master Chef (TVN) czy edukacyjna kreskówka Tajemnicza kuchnia przygotowana przez serwis Ciufcia.pl. Programy te popularność zawdzięczają australijskiej serii Gotowanie dla dzieci z Luisem (Cooking for Kids with Luis) wyprodukowanej w 2004 roku oraz hiszpańskiej animacji Tomek i Tunia gotuja (Telmo and Tula Little Cooks, 2006).

Rynek oferuje najmłodszym odbiorcom rozmaite gry o tematyce kulinarnej. Wśród nich można znaleźć między innymi gry planszowe (Owocowy wyścig, Egmont 2014; Królewski kucharz, Trefl 2015), zręcznościowe (Gra kanapka 10 w 1, Melissa and Doug 2015), online (Lekcje gotowania z Sara dostępne na portalu Gry.pl), a także wiele oryginalnych projektów, umożliwiających wcielenie się na czas podjętej gry/zabawy, w rolę szefa kuchni, restauratora, kucharza czy dekoratora ciast i potraw.

Przemysł filmowy tworzy pełnometrażowe produkcje skierowane do dziecięcego widza, w których motywem przewodnim jest gotowanie, jak kultowy Ratatuj (Ratatouille, reż. B. Bird, USA 2007) czy Klopsiki i inne zjawiska pogodowe (Cloudy with a Chance of Meatballs, reż. Ch. Miller i P. Lord, USA 2009) na podstawie książki Judi Barrett pod tym samym tytułem. Popularne czasopisma dziecięce i młodzieżowe drukują (stałe i okazjonalne) rubryki z przepisami i poradami na świąteczne menu (na przykład „Barbie. Zabawy i Marzenia”, „Bravo Girl”). Natomiast wydawcy książek dla najmłodszych, powielając sprawdzone trendy rynku wydawniczego dla dorosłych, chętnie publikują książki kucharskie, poradniki na temat organizacji dziecięcych party oraz beletrystykę z motywami jedzenia i przepisami kulinarnymi. Przykładem tej ostatniej kategorii jest seria kryminałów dietetycznych „Walenty i Spółka” Moniki Oworuszko z wydawnictwa Mobuki ${ }^{4}$

1 Zob. G. Ritzer, Magiczny świat konsumpcji, przeł. L. Stawowy, Warszawa 2001; J. Baudrillard, Społeczeństwo konsumpcyjne - jego mity i struktury, przeł. S. Królak, Warszawa 2006; B.R. Barber, Skonsumowani. Jak rynek psuje dzieci, infantylizuje dorostych i połyka obywateli, przeł. H. Jankowska, Warszawa 2009.

2 Zob. J. Cieślikowski, Literatura i podkultura dziecięca, Wrocław 1974.

3 Zob. R. Kossakowski, Uprzedmiotowione i „obrandowane”: dzieci w kulturze towarów, „Teraźniejszość - Człowiek - Edukacja” 2011, nr 1, s. 21-39.

${ }^{4}$ Na cykl składają się tomy: Kryminat dietetyczny, Warszawa 2015; Walenty i spótka ruszaja w świat, Warszawa 2015; Walenty i spótka buduja piramidę, Warszawa 2015; Walenty i spótka szukają witamin, Warszawa 2016; Walenty i spółka podróżuja w czasie, Warszawa 2017. 
i włoski cykl sensacyjny „Banda Spaghetti”, opublikowany w Polsce przez Grupę Wydawniczą Foksal ${ }^{5}$.

Ważny kontekst rynkowego funkcjonowania książek kucharskich adresowanych do dzieci stanowią media i technologie cyfrowe. Ich rozwój umożliwił przeobrażenia kanałów dystrybucji, krystalizację nowych form promocji tego typu publikacji, a także ewolucję oryginalnych form edytorskich, do których należą kulinarne książki-zabawki, abecadlniki, elementarze, słowniczki kulinarne, wierszowane książki kucharskie ${ }^{6}$ itp. W efekcie rozwoju nowoczesnych sposobów zapisu i przekazu dzieł piśmienniczych na rynku książek kucharskich dla dzieci pojawiły się z kolei kulinarne audiobooki (na przykład Płyta do zjedzenia), ebooki (na przykład Basia i słodycze, Basia i gotowanie, Szarlotka pachnaca marzeniami), aplikacje na urządzenia mobilne (na przykład Gratka dla małego niejadka na postawie książki Emilii Dziubak pod tym samym tytułem) ${ }^{7}$ oraz tematyczne projekty internetowe, jak chociażby blog kulinarny Cecylka Knedelek ${ }^{8}$ — projekt dedykowany serii książek kucharskich dla najmłodszych autorstwa Joanny Krzyżanek. Najmłodsi użytkownicy, odwiedzając tę witrynę, mogą aktywnie uczestniczyć w grach, zabawach i konkursach kulinarnych, pobierać tapety i wygaszacze do komputera, a ponadto uzyskują dostęp do materiałów poświęconych cyklowi o sympatycznej Cecylce. Tego rodzaju rozwiązania należy uznać oczywiście za advertainment stosowany przez wydawców jako narzędzie służące podtrzymaniu zaangażowania dziecięcych odbiorców oraz „przywiązaniu” ich do marki.

Obieg współczesnych książek kucharskich dla dzieci dokonuje się w środowisku kultury konsumpcyjnej w wysokim stopniu mediatyzowanej. W jej kręgu znajdują się różnorodne przekazy medialne, z którymi książki te wchodzą w mniej czy bardziej złożone relacje, tworząc siatki wielowymiarowych powiązań. Rozszerzanie się zjawiska na media społecznościowe pozwala wysunąć tezę o wyodrębniającym się z całości kultury, wspólnym segmencie, współtworzonym przez zróżnicowane materiałowo teksty kulinarne dla dzieci i młodzieży, ich au-

5 Zob. C. Capria, M. Martucci, Sprawa złotego widelca, przeł. N. Mętrak, Warszawa 2013; Sprawa skradzionego roweru, przeł. N. Mętrak, Warszawa 2013; Sprawa konkursu ciast, przeł. N. Mętrak, Warszawa 2014; Sprawa zaginionego psa, przeł. N. Mętrak, Warszawa 2014.

${ }^{6}$ A. Has-Tokarz, Kulinarne rymowanki... - o wierszowanych ksiażkach kucharskich dla dzieci (w perspektywie bibliologicznej), referat wygłoszony podczas konferencji naukowej Kuchnia i stół w komunikacji społecznej. Tekst - Dyskurs - Kultura, 15-18 października 2015, Wrocław [maszynopis].

${ }^{7}$ Szerzej na temat wielowymiarowości zjawiska aneksji przestrzeni mediów i Internetu przez książki kucharskie dla dzieci zob. A. Has-Tokarz, Bajty do zjedzenia - ksiązki kucharskie dla dzieci w przestrzeni (nowych?) mediów, referat wygłoszony podczas konferencji naukowej Kultura ksiązki w humanistyce wspótczesnej, 23-24 listopada 2016, Wrocław [mps].

${ }^{8}$ Zob. cecylkaknedelek.pl (dostęp: 20.05.2017). Obecnie jego kontynuację stanowi profil na Facebooku: https:/www.facebook.com/pages/category/Book/Cecylka-Knedelek-198274963610308/ (dostęp: 6.06.2020). 
torów, wydawców/producentów oraz coraz liczniejsze grono młodych odbiorców/ konsumentów.

\section{Książki kucharskie jako poszerzenie systemów rozrywki dla dzieci}

Wśród książek kucharskich dla dzieci dynamicznie rozwija się kategoria ściśle powiązana z rozrywkowym przemysłem medialnym. Chodzi tu o poradniki kucharskie będące elementem tak zwanych systemów rozrywki, tworzonych z myślą o najmłodszych odbiorcach/konsumentach popkultury. Marsha Kinder rozumie pod tym pojęciem ,intertekstualną sieć zbudowaną wokół jednej lub grupy postaci z kultury popularnej, które są fikcyjne [...] bądź »rzeczywiste«"9. Jej zdaniem specyficzne dla tej sieci jest wykorzystywanie wielu trybów produkcji i obrazów, przemawianie do różnych pokoleń, klas, subkultur etnicznych oraz zachęcanie do kolekcjonowania poprzez mulitiplikację pokrewnych artykułów. Do idei amerykańskiej badaczki nawiązuje Michał Zając w koncepcji „Produktu Totalnego”, postrzeganego jako „komunikat symboliczny [...], którego postacie medialne tworzą rozbudowany system przekazów mogący pojawić się w każdym z kontaktów odbiorcy z kulturą jako taką" ${ }^{10}$. Własnością immanentną tak pojmowanych produktów dla dzieci jest ,zaniknięcie granicy pomiędzy reklamą a jej przedmiotem z punktu widzenia nadawcy i odbiorcy"11.

Z tymi ujęciami koresponduje idea transmedia storytelling Henry'ego Jenkinsa. Badacz pod pojęciem tym rozumie ,wielowątkową i zróżnicowaną historię, która odsłaniana jest na różnych platformach medialnych, przy czym każde medium ma swój oddzielny wkład w tworzenie i rozwijanie fikcyjnego świata"12. W ramach estetyki narracji transmedialnej znane fabuły opowiadane są za pomocą różnych form przekazu, ale odnoszą się do jednego świata przedstawionego, zachowując jednocześnie autonomię i samowystarczalność, dzięki czemu konsument może wybrać dowolny rodzaj dostępu do określonej marki. W systemach rozrywki każdy pojedynczy artykuł, figurka do zabawy, nalepka, gra, książka, komiks, film itp. odsyła odbiorcę do całego systemu/produktu, zwiększając popularność i sprzedaż pozostałych rekwizytów.

W przywołanych stanowiskach mowa jest de facto o przenoszeniu stałych elementów pomiędzy mediami i/lub tekstami, dzięki którym system/produkt/

${ }^{9}$ M. Kinder, Playing with Power in Movies, Television, and Video Games, Berkeley 1991, s. $122-123$.

10 M. Zając, Koncepcja Produktu Totalnego, [w:] idem, Promocja książki dziecięcej. Podręcznik akademicki, Warszawa 2000, s. 163.

11 Ibidem, s. 164.

12 H. Jenkins, Kultura konwergencji. Zderzenie starych i nowych mediów, przeł. M. Filiciak, Warszawa 2007, s. 260. 
opowieść istnieje jako organiczna całość, rozpoznawalna przez odbiorców. Najważniejsze pod tym względem są postacie, które dominują nad fabułą i instancją autorską, czego skutkiem jest zatarcie relacji chronologicznych między poszczególnymi produktami funkcjonującymi w ramach systemu. Oznacza to, że systemy rozrywki nie mogą istnieć bez wizualnej wersji prowadzącej zjawisko. Na ogół jest to postać bohatera (lub grupa postaci), nierzadko występująca jako inicjalna forma zaistnienia systemu na rynku medialnym, wobec której zachodzi marketingowa „reguła lubienia”. Postać/bohater systemu dziecięcej rozrywki jest prezentowana w sposób ustandaryzowany, gdyż musi być zrozumiała dla zróżnicowanych wiekowo i komunikacyjnie grup odbiorczych oraz identyfikowana globalnie i w różnych środowiskach kulturowych.

Chodzi tu o postaci w pewnym sensie kultowe, wytwory globalnej popkultury, a jednocześnie reprezentacyjne marki rynku dla dzieci i młodzieży, do których także dorośli odbiorcy wracają z sentymentem. Za każdą z tych postaci/ikon stoi konkretny charakter, pełna przygód fabuła, plastyczny język i wizualizacja. Wynika to z faktu, że najmłodsi odbiorcy nieomylnie rozpoznają twarz czy sylwetkę, którą widzieli wcześniej, zwłaszcza jeśli postać jest charakterystyczna, jak ma to miejsce w przypadku bohaterów bajkowych. Dorośli konsumenci również nie zawsze mają ochotę wytężać umysł, aby odnaleźć analogiczność przebiegu wydarzeń w heterogenicznych tekstach, ale zwracają uwagę na oglądanych wielokrotnie bohaterów.

\section{Smakolyki, Przysmaki i inne... - książki kucharskie Kubusia Puchatka}

Rozpoznawalnym bohaterem dziecięcej wyobraźni i postacią wiodącą w globalnym systemie rozrywki jest Kubuś Puchatek, wykreowany niemal sto lat temu przez angielskiego pisarza Alana Alexandra Milne'a. Korowód tekstów medialnych i produktów związanych $\mathrm{z}$ tą bajkową postacią został poszerzony także o książki kucharskie.

W 1991 roku ukazała się komiksowa Książka kucharska Kubusia Puchat$k a^{13}$, wydana na licencji Walta Disneya przez firmę Egmont. Publikacja składa się z sześciu rozdziałów: Zupy i małe Conieco (na przykład „Grzanka z jajkiem Kubusia Puchatka”, „Kukurydziany krem Krzysia” czy „Hamburger Tygrysa”), Dania ciepłe (na przykład „Serowy pudding Prosiaczka”, „Wołowina Kangurzycy”), Dania zimne (na przykład „Zawijanki Maleństwa”, „Sałatka owocowo-serowa Kłapouchego"), Uroczystości (urodzinowe przyjęcia) (na przykład „Pasta Puchatka”, „Marcepanowe pszczoły Puchatka”), Słodkie Conieco (zawierający przepisy na ciasteczka i desery) oraz Wyśmienite, pysznościowe Conieco do pi-

13 Zob. Książka kucharska Kubusia Puchatka, przeł. M.A. Jaworowski, Warszawa 1991. 
cia. Wykonanie każdej potrawy krok po kroku wizualizują całostronicowe ilustracje utrzymane w stylu grafiki komiksowej, z kolorowymi rubrykami, w których wyodrębniono składniki potraw i niezbędne narzędzia kuchenne (Co jest Ci potrzebne). Wstęp do książki zawiera edukacyjne uwagi na temat zasad zachowania bezpieczeństwa w kuchni (Ostrożność to bezpieczeństwo) i Wykaz miar i wag podstawowych produktów spożywczych.

U schyłku dekady lat dziewięćdziesiątych XX wieku oficyna Prószyński i S-ka wydała kolekcjonerską serię kucharską inspirowaną „osobą” Misia o Bardzo Małym Rozumku, ale za to wielkim apetycie, współtworzoną przez trzy tematyczne tomiki z oryginalnymi ilustracjami Ernesta Sheparda. Tom Kubuś Puchatek zaprasza na podwieczorek i małe Conieco... ${ }^{14}$ nawiązuje bezpośrednio do brytyjskiej tradycji celebrowania podwieczorku, który jest jednocześnie popularnym posiłkiem przedszkolaków. Publikacja gromadzi kilkadziesiąt przepisów na słodkie przysmaki, takie jak nadziewane bułeczki do jedzenia na ciepło, ciasta i ciasteczka, słodkie dżemy, a także propozycje na grzanki, kanapki i pyszne napoje. Książeczka Kubuś Puchatek zaprasza na piknik ${ }^{15}$ zawiera czterdzieści receptur na dania biwakowe, między innymi na paluszki z kurczaka z orzechami laskowymi, herbaciany poncz z miodem i przyprawami korzennymi, smaczne ciasteczka czekoladowe i wiele innych. Przepisy zostały uzupełnione poradami dotyczącymi przygotowania pikników dla dzieci (w deszczowy dzień lub na plaży), przyjęcia urodzinowego i biwaku podczas wspólnej wyprawy z przyjaciółmi. Kubuś Puchatek zaprasza na ciasteczka ${ }^{16}$ jest zbiorem receptur na wypieki: zawijane, lane, herbatniki i ciastka zmrożone. Wiele z tych słodkości otrzymało w książeczce ujmujące nazwy, nierzadko wprost nawiązujące do imion mieszkańców Stumilowego Lasu, jak na przykład „Guziczki Krzysia” czy „Tygryski”.

$\mathrm{Z}$ postacią najsłynniejszego misia świata powiązane są dwie kartonowe książeczki kulinarne dla najmłodszych wydane przez oficynę Egmont w ramach edukacyjnej serii „Disney. Kubuś i Przyjaciele”. Są to Przysmaki i Smakołyki ${ }^{17}$, wprowadzające jeszcze nieczytające dzieci w świat najprostszych pojęć kulinarnych i reguł zdrowego odżywiania. Przykładowo w Przysmakach najmłodsi poznają wartości odżywcze niektórych produktów (na przykład żółtego sera), nowe owoce i warzywa (na przykład arbuz, marchew, dynia) i rymowane, łatwe do zapamiętania, przepisy na polecany przez Królika „sok z marchwi” czy „prosiaczkową” zupę dyniową („Stoi w kuchni gar olbrzymi, Co jest w garnku? Zupa z DYNI! Kto ją zaraz

14 Zob. Kubuś Puchatek zaprasza na podwieczorek i małe Conieco: tekst inspirowany „Kubusiem Puchatkiem " $i$, Chatka Puchatka” 'A.A. Milne'a, cytaty z książek przeł. I. Tuwim, przepisy przeł. A. Semkowicz, il. E.H. Shepard, Warszawa 1999.

15 Zob. Kubuś zaprasza na piknik [wg A.A. Milne’a], cytaty z książek przeł. I. Tuwim, przepisy przeł. A. Semkowicz, il. E.H. Shepard, Warszawa 1999.

${ }^{16}$ Zob. Kubuś Puchatek zaprasza na ciasteczka wg A.A. Milne'a, cytaty z książek przeł. I. Tuwim, przepisy przeł. A. Semkowicz, il. E.H. Shepard, Warszawa 1999.

17 Zob. N. Usenko, Smakołyki, Warszawa 2013; eadem, Przysmaki, Warszawa 2013. 
zje? Prosiaczek! Ma miseczkę i śliniaczek...") ${ }^{18}$. Potrawy te, zdaniem bohaterów bajki, smakują znacznie lepiej niż kaloryczna babeczka z różowym kremem, co zachęca dziecięcych czytelników do skosztowania dań zdrowych, promowanych przez ich ulubieńców. Bez wątpienia książeczki łączą zabawę językowo-literacką $\mathrm{z}$ alfabetyzacją kulinarną najmłodszych.

Z omawianą marką powiązana jest książeczka kulinarna Kubuś Puchatek. Zaproszenie na herbatke $e^{19}$, wydana przez Egmont w edukacyjnej serii „Puchatkowe Zabawy”, a ponadto poradnik Kubuś i przyjaciele. Jak przygotować przyjęcie krok po kroku ${ }^{20}$. Zawierają one inspiracje na imprezy okolicznościowe dla przedszkolaków, pomysły na wykonanie stosownego nakrycia stołu i ozdób, tematyczne zabawy i jadłospis na „misiowe” party.

\section{Kaczor Donald, Myszka Miki i inni bohaterowie Disneya zapraszają do stołu}

Rynek wydawniczy oferuje wiele książek kucharskich i poradników kulinarnych powiązanych z bohaterami popularnych kreskówek i filmów animowanych dla najmłodszych, wyprodukowanych w wytwórni Walta Disneya. Książki kucharskiej doczekał się Kaczor Donald, powołany do życia w 1934 roku. Utrzymana w komiksowej stylistyce Książka kucharska Kaczora Donalda ${ }^{21}$ została wydana przez Egmont w 1995 roku. Zawiera przepisy na potrawy śniadaniowe, obiadowe, desery i słodkości, jak ciasto czekoladowe, słodkie bułeczki, „Orzechowe placuszki Hyzia, Dyzia i Zyzia” czy popularną „pizzę Kaczora Donalda” $\mathrm{z}$ dodatkiem kiełbasy i cebuli.

Inną propozycją wydawnictwa jest kartonowa książeczka Do stołu! Zaprasza do stolu swych przyjaciół Miki ${ }^{22}$ opracowana przez Zuzannę Naczyńską. Miłośnicy Myszki Miki nie znajdą w publikacji gotowych receptur. Umieszczono tu podpowiedzi, jak przygotować przyjęcie z nietypowym menu, gdzie wiodącymi przekąskami są naleśniki i tort urodzinowy w kształcie najsłynniejszej myszy świata oraz literkowe ,precle do chrupania”.

Rady dotyczące organizacji dziecięcych uroczystości i propozycje okolicznościowych jadłospisów zawierają poradniki Samoloty 2. Jak przygotować przyję-

18 N. Usenko, Przysmaki, s. 10-11.

19 Zob. Kubuś Puchatek. Zaproszenie na herbatkę, wiersze N. Usenko, oprac. graf. G. Janecka, Warszawa 2010.

${ }^{20}$ Zob. Kubuś i przyjaciele. Jak przygotować przyjęcie krok po kroku. Pomysty na menu, zabawy. Dekoracje, Warszawa 2014.

${ }^{21}$ Zob. Ksiązka kucharska Kaczora Donalda, przeł. J. Tarsała, Warszawa 1995.

22 Zob. Z. Naczyńska, Do stołu!, Warszawa 2011. 
cie krok po kroku ${ }^{23}$ i Auta. Jak przygotować przyjęcie krok po kroku ${ }^{24}$. Kreatywne zeszyty zostały tym razem skierowane bezpośrednio do chłopców w wieku przedszkolnym. Publikacje nawiązują do pełnometrażowych filmów animowanych wyprodukowanych przez Pixar we współpracy z firmą The Walt Disney Company. Zawierają wskazówki, jak przygotować „samolotowe” i ,samochodowe” przyjęcie dla przyjaciół (w domu, w wynajętej sali zabaw lub na świeżym powietrzu), inspirujące wzorniki z listą gości, szablony zaproszeń i drobiazgów do dekoracji sali oraz stołu, wykroje kostiumu i ozdób dla gości, propozycje podania jedzenia w wyszukany sposób. W poradnikach znalazły się przepisy na smaczne torty urodzinowe (samolotowy lub samochodowy tort jeep) dekorowane kolorowymi posypkami, czekoladowymi drażami, kawałkami owoców i receptury na wiele innych przysmaków dla „prawdziwych rajdowców” (Auta) lub „prawdziwych pilotów” (Samoloty 2), jak sałatka „leniwe krokodyle” z tuńczykiem i ogórkiem czy słodkie „kuleczki owsiane”. Potwierdzeniem sukcesu urodzinowych propozycji kulinarnych Zielonej Sowy jest liczba dotyczących ich wiadomości, zamieszczonych na stronach WWW popularnej wyszukiwarki internetowej Google, liczona w setkach tysięcy (na przykład inspirander.pl/przyjecie/przyjecie-auta).

Gigantyczna firma twórcy rozrywkowych parków tematycznych zarządza gamą produktów, które współdziałając, „wzajemnie się sprzedają, w ramach ściśle zintegrowanego systemu"25. Założycielowi Disneylandu chodziło o wykreowanie „maszyny do sprzedawania”, która zapewni dystrybucję firmowych artykułów na globalnym rynku. Taki spójny system sprzedaży, w którym jeden towar generuje sprzedaż kolejnych (zgodnie z zasadą „everyting sells everyting else”, czyli „,każdy towar promuje każdy inny” lub „wszystkie produkty promują się nawzajem”), to modelowy przykład mechanizmu marketingowego służącego multiplikacji sprzedaży i w efekcie konsumpcji ${ }^{26}$.

Przykładem realizacji tej strategii jest album kulinarny z naklejkami Gotuj z nami! Magiczna księga zdrowych przepisów, udostępniony w Polsce w 2015 roku przez sieć supermarketów Carrefour w ramach akcji promocyjnej „Rodzinne gotowanie z bohaterami Disneya". Jak zaznacza wydawca, publikacja ta ma służyć „,wspólnemu odkrywaniu świata kulinariów” przez dzieci, ich rodziców/ opiekunów i bajkowych ulubieńców. W książce znalazły się kucharskie propozycje inspirowane postaciami z takich filmowych animacji, jak: Miki \& Minnie, Ratatuj, Kubuś Puchatek, Wróżki, Kopciuszek, Auta, Samoloty, Potwory i Spótka, Iniemamocni, Toy Story, Kraina Lodu, Gdzie jest Nemo? i Król Lew.

23 Zob. Samoloty 2. Jak przygotować przyjęcie krok po kroku. Pomysty na menu, zabawy. Dekoracje, Warszawa 2014.

24 Zob. Auta. Jak przygotować przyjęcie krok po kroku. Pomysty na menu, zabawy. Dekoracje, Warszawa 2014.

25 G. Ritzer, op. cit., s. 20.

${ }^{26}$ Zob. B. Capodagli, L. Jackson, Metoda Disney'a. Jak skutecznie wykorzystać tajemnice zarządzania Disney'a w twojej firmie, przeł. M. Rusiński, K.E. Lieber, Warszawa 2002. 
Książka zawiera kilkadziesiąt przepisów na: śniadania, przystawki, dania główne, desery i napoje, zebranych w odpowiadających tematycznie rozdziałach. Zgromadzono w niej receptury standardowe na dania często pojawiające się w dziecięcych książkach o gotowaniu, jak pizza, parówki, tosty czy grzanki, ale także kilka propozycji wykwintnych (Kraina Lodu na przykład serwuje „Bordowe monety", czyli buraczki pieczone w plasterkach podawane z wytrawnym sosem vinegrette). W książce podanych jest wiele bajkowych „sposobów” na przyrządzenie i serwowanie zdrowego dania dla tak zwanych niejadków. Już sama nazwa potrawy ma zachęcać dzieci i rodziców/opiekunów do jej przygotowania. „Lwi przysmak”, „pajęcza zupa”, „chrupiące śmigła”, „przysmak rajdowca”, „buźki pełne warzyw”, „odlotowe tortille" to tylko niektóre z przekąsek proponowanych w albumie. Projekt wydawniczy jest potwierdzeniem, że postaci z popularnych kreskówek doskonale sprawdzają się w marketingu ,jedzeniowym”. Jest swego rodzaju wehikułem reklamowym — okazją do product placement. Wiele miejsca zajmują tu reklamy konkretnych artykułów spożywczych, pokazywane na ilustracjach $w$ oryginalnych opakowaniach i zabawek $z$ widocznym logo producenta, często z zachęcającym zdaniem, podkreślającym zalety konkretnego produktu.

\section{Patelnie, rondle, chochle i... księżniczki Disneya}

Gotuj razem z Tiana! Przepisy dla dzieci ${ }^{27}$ to książka kucharska inspirowana disnejowskim filmem animowanym Księżniczka i żaba (reż. R. Clements i J. Musker, USA 2009) opartym na motywach książki Elisabeth Dawson Baker pod takim samym tytułem, inspirowanej z kolei baśnią braci Grimmów Żabi król. Zebrano w niej przepisy na dania, które protagonistka — księżniczka Tiana — jadała w swoim rodzinnym domu i podawała w stworzonej przez siebie restauracji. Receptury podzielono na pięć kategorii: pożywne śniadania, pyszne przekąski, obfite obiady, pieczywo, dodatki i napoje oraz deserowe delicje.

Wśród dwudziestu czterech przepisów znalazły się słynne „,kwadratowe pączki Tiany”, „babka Charlotte” (z warstwą cynamonowej kruszonki), „kanapka Tatucha”, „sałatka owocowa doktora Faciliera”, jazzowa jambalaya, czerwona fasola z ryżem, chlebek kukurydziany, koktajl z bagien, mrożona herbata, lodowy „deser Raya”, pudding chlebowy z ananasem i owoce z pieca. Część potraw jest prosta w przygotowaniu i nie wymaga stosowania wymyślnych składników, jak chociażby grzanki z bananami czy frytki z piekarnika. W przypadku innych konieczna jest pomoc dorosłych albo poszukanie rzadkich produktów, na przykład do „fasolki Naveena” potrzebne są kasztany wodne, a do „lemoniady Juju” bezalkoholowe piwo imbirowe.

27 Zob. Gotuj razem z Tiana: przepisy dla dzieci, przekł. i adaptacja przepisów Z. Naczyńska, Warszawa 2011. 
Pojedyncze przepisy zajmują dwie strony i składają się z krótkich wprowadzeń zawierających informacje o historii dań, pochodzeniu oryginalnych nazw potraw, ich walorach wizualnych lub smakowych oraz związku z konkretnymi postaciami bajkowymi. Wyjątkowo pojawiają się porady dotyczące składników zastępczych, dekoracji potraw czy praktycznego wykorzystania resztek. Dodatkowo przepisy zostały opatrzone oceną stopnia trudności od jednego do pięciu, wyrażoną w „skali żab”. Każdemu przepisowi towarzyszy całostronicowa fotografia gotowej potrawy. W edukacyjnym wstępie zawarto uwagi i rady dotyczące między innymi pojemności stosowanych naczyń, zachowania czystości w kuchni, zasad bezpieczeństwa w obchodzeniu się z ostrymi przedmiotami kuchennymi, piekarnikiem i gorącymi naczyniami, stosowania tajemniczego „składnika miłości” niezbędnego — zdaniem Tiany — aby danie było udane i smaczne.

Od czasu wydania książki kucharskiej księżniczki Tiany pojawiło się wiele innych poradników kulinarnych, które wiążą się z bohaterkami animacji Disneya. W 2014 roku ukazały się kreatywne zeszyty: Księżniczki. Jak przygotować przyjęcie krok po kroku ${ }^{28}$ oraz Wróżki. Jak przygotować przyjęcie krok po kroku ${ }^{29}$. Oprócz rad, jak zaplanować przyjęcie urodzinowe, w co się na nie ubrać, w jaki sposób udekorować stół i w co się bawić z gośćmi, zawierają one projekt uroczystego menu, którego motywami przewodnimi są Kopciuszek i Bella, a w drugim wypadku Dzwoneczek i jej przyjaciele.

Dzięki fankom temat gotujących księżniczek podlega swoistej „wędrówce powtórzeń" w mediach. Ilustracją jest tu blog Gruszka z Fartuszka, na którym autorka zamieściła efekty własnego projektu kulinarno-fotograficznego Bajeczne desery inspirowane księżniczkami Disneya. To niekonwencjonalne przedsięwzięcie artystyczne obejmuje dwanaście fotografii kulinarnych oraz poświęcone im receptury. Bohaterkami wystylizowanych zdjęć są potrawy i księżniczki: Królewna Śnieżka (jabłko w karmelu), Kopciuszek (dyniowe cake pops), Śpiąca Królewna (malinowa pianka na biszkopcie przekładanym dżemem), Arielka (makaroniki z kokosowym kremem), Bella (Gruszki Pięknej Heleny, czyli gotowane gruszki w czekoladzie), Jasmine (mus sułtański z rumem i rodzynkami), Pocahontas (orzechowy biszkopt z kremem czekoladowo-pekanowym), Mulan (ciasteczka $\mathrm{z}$ wróżbą z polewą z białej czekolady i herbaty mocha), Tiana (lody na patyku $\mathrm{z}$ awokado i bananami), Roszpunka (miodowe lody z lawendą), Merida (jabłkowo-owsiane copcake's z kremem kajmakowym) i Elsa (galaretka przekładana musem migdałowym) $)^{30}$.

28 Zob. Księżniczki. Jak przygotować przyjęcie krok po kroku. Pomysty na menu, zabawy. Dekoracje, Warszawa 2014.

29 Zob. Wróżki. Jak przygotować przyjęcie krok po kroku. Pomysły na menu, zabawy. Dekoracje, Warszawa 2014.

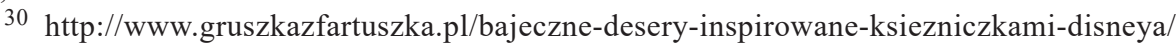
(dostęp: 20.03.2017). 


\section{Mam natchnienie na jedzenie!, czyli gotowanie z Garfiledem i Gusteau}

Książki kucharskiej doczekał się rudy kocur o imieniu Garfield, znany za sprawą popularnego komiksu, serialu telewizyjnego i pełnometrażowej animacji. Ilustrowany poradnik Mam natchnienie na jedzenie! ${ }^{31}$ ukazał się w Polsce w 2005 roku. Publikacji towarzyszył światowy rozgłos, jakim cieszył się film o przygodach ekscentrycznego kota. Egmont wydał Książkę kucharska Garfielda z okazji jubileuszu obecności marki „Garfield” na globalnym rynku (kocura stworzył u schyłku lat siedemdziesiątych XX wieku amerykański rysownik Jim Davis). W publikacji znalazły się rozdziały o jedzeniu dla całej rodziny, potrawach na okolicznościowe przyjęcia, makaronach (wszak daniem szczególnie drogim Garfieldowi jest lasagne), przekąskach z grilla, deserach. Nie zabrakło także przepisów dla dzieci.

Z kolei szczurza rodzina zamieszkująca paryską restaurację Gusteau, znana za sprawą filmu Ratatuj, zrealizowanego w wytworni Disney-Pixar, przejmuje noże i patelnie w publikacji Ratatuj. Tak wielu kucharzy ${ }^{32}$. Ta wierszowana książka Margaret McNamary jest familijnym poradnikiem kucharskim, w którym poruszono ważne kwestie na temat gotowania. Jest tu mowa o obowiązku zachowania czystości przez kucharza, wstępnych przygotowaniach kuchni, rozmaitych technikach kulinarnych, jak smażenie sauté czy flambirowanie, oryginalnych przyprawach (szafran, sos aïoli) i potrawach (ragoùt, profiterolki, francuski suflet i tytułowe $r a$ tatouille). Do książki dołączono minisłowniczek objaśniający znaczenie dwunastu najtrudniejszych terminów kulinarnych i francuskich słów. Książka została wydana w edycji kolekcjonerskiej: w dużym formacie, twardej oprawie, na kredowym papierze. Jej wnętrze zdobią nie tylko fotografie potraw, lecz także całostronicowe ilustracje Nate'a Wragga, nawiązujące do kadrów z disnejowskiej animacji.

Z filmem o kuchennych przygodach szczurka Remy'ego wiąże się wypełniona barwnymi fotografiami gotowych potraw publikacja Gotuj razem z Gusteau: książka kucharska dla dzieci ${ }^{33}$. Wstęp i część przepisów do niej opracował Thomas Keller, szef kuchni i właściciel sławnych restauracji French Laundry, Bouchon i Per Se, zdobywca wielu prestiżowych nagród Fundacji Jamesa Bearda. Restaurator występuje tu w roli niekwestionowanego autorytetu/eksperta, swoim nazwiskiem i twarzą ma gwarantować nabywcom książki (w wypadku książki dla dzieci jest to dorosły) jej wysoką jakość i wartość. Jednocześnie staje się instrumentem tak zwanego celebrity marketing. Osoba sławna przyciąga uwagę, zwiększa oglądalność, „klikalność”, słuchalność itp. Stąd rosnąca rola celebrytów w przemyśle medialnym, który korzysta z ekonomicznej „,premii sławy”.

31 Zob. J. Davis, Mam natchnienie na jedzenie. Ksiązka kucharska Garfielda, przepisy B. Albright, przeł. A. Niedźwiecka, Warszawa 2005.

${ }^{32}$ Zob. M. McNamara, Ratatuj. Tak wielu kucharzy, il. N. Wragg, Warszawa 2007.

33 Zob. Ratatuj. Gotuj razem z Gusteau: ksią̇ka kucharska dla dzieci, przeł. Z. Naczyńska, wstęp i jeden z przepisów T. Kelner, Warszawa 2008. 


\section{Gotowanie z Pszczółką Mają i Martynką}

Książka Gotujemy! Pszczótka Maja ${ }^{34}$ została opracowana na podstawie opowiadań niemieckiego pisarza Waldemara Bonselsa Pszczółka Maja i jej przygody wydanych po raz pierwszy w 1912 roku, które stały się kanwą popularnego na całym świecie serialu animowanego dla dzieci. Publikacja zawiera praktyczne porady dla małych kucharzy i przepisy, podzielone „funkcjonalnie”: zdrowe śniadanie, pyszne przekąski, dania główne, słodkości, napoje i przekąski na dziecięce przyjęcia. Wśród proponowanych receptur można znaleźć przepisy na potrawy wegetariańskie, na przykład „bułkę z bananem” (właściwie bananowe rogaliki), bananowy chleb, kanapki z kiwi, „regaty z paluszków rybnych”, oraz dania mniej dietetyczne, jak czekoladowa pizza, makarony, „serdelkowa dżdżownica”, „płonące wigwamy”, omlet serowy czy ,świnki w ogródku owocowym”. Prostota zebranych receptur sprawia, że dzieci mogą je przyrządzić samodzielnie lub w asyście dorosłych. Przepisy objaśniono krok po kroku i opatrzono barwnymi fotografiami wizualizującymi już ukończoną potrawę i sposób jej serwowania. Kolorowe oznaczenia $\mathrm{z}$ garnkami podpowiadają małym kuchmistrzom, jakich umiejętności wymaga każda potrawa, a dołączona lista składników ułatwia przygotowania do gotowania. Książka zawiera też edukacyjne rozdziały: Nakrywanie do stołu, Trzy garnki, Rady pszczótki Mai i Kuchenne ABC.

Dziecięcą przewodniczką po kulinarnym świecie jest również Martynka bohaterka bestsellerowej serii belgijskich autorów Gilberta Delahaye i Huberta Colsona. Kuchnia Martynki. Najlepsze przepisy ${ }^{35}$ to zbiór dwudziestu czterech przepisów na słodkości, które dzieci mogą przygotować samodzielnie lub w asyście dorosłych. Pretekstem do familijnej zabawy w kuchni mogą być święta i inne ważne uroczystości w roku. Oprócz receptur na świąteczne smakołyki, jak ,jesienny jabłecznik cioci Lusi”, noworoczne ciasto czekoladowe, ciasteczka urodzinowe, migdałowe babeczki czy wyśmienite lody waniliowe w książce znalazły się: przelicznik miar, słowniczek kulinarny, wierszyki i ciekawostki kulinarne (na przykład rodzaje cukru), miejsce na własne zapiski. Przepisom towarzyszą informacje o koniecznych przyborach kuchennych i składnikach niezbędnych do przygotowania ciasta.

Do aktywności kulinarnej zachęcają najmłodszych również wydane w serii o Martynce książeczki literackie Martynka w kuchni ${ }^{36}$ oraz Martynka i 40 kuch$c i k o ́ w^{37}$. Pierwsza zawiera uwagi o miarach i wagach oraz zachowaniu porządku

34 Gotujemy! Pszczółka Maja, na podst. opowiadań W. Bonselsa, przeł. M. Szpak, Ożarów Mazowiecki 2008.

35 Zob. H. Colson, Kuchnia Martynki. Najlepsze przepisy zilustrowane krok po kroku, il. N. Charlet, przeł. E. Łukaszczyk, Poznań 2009

36 Zob. G. Delahaye, M. Martier, Martynka w kuchni, oprac. W. Chotomska, Poznań 2001.

37 Zob. G. Delahaye, M. Martier, Martynka i 40 kuchcików, oprac. W. Chotomska, Poznań 2008. 
w kuchni, nierzadko podane w sposób humorystyczny, na przykład „Szklanka, łyżeczka, łyżka i waga, każdej kucharce w kuchni pomaga” czy „Jeśli będzie bałagan, to może się zdarzyć, że sól wyląduje w kompocie, a czekolada w zupie...". Znalazły się w niej także przepisy na „Chlebojaje”, czyli tosty w jajku podawane na gorąco, majonez własnoręcznie kręcony, mus czekoladowy, jabłko z dziurką, „delicje Alicji”, czyli konfitury z truskawek, „naleśniki babci Ludwiki” smarowane konfiturami „złożone w trójkąt lub zwinięte w rulonik"38. W książce Martynka i 40 kuchcików najmłodsi czytelnicy mają okazję odbyć „kurs gotowania” z ulubioną bohaterką. Dowiedzą się, że „Dobry kucharz zawsze wybiera świeże produkty", należy sprawdzać termin ważności podany na opakowaniu, jak rozróżniać smaki przekąsek (słodki, gorzki, kwaśny, słony), jak rozpoznać zapachy ziół i przypraw (majeranku, cynamonu, goździków, mięty, bazylii, wanilii) i jakie mają zastosowanie w gotowaniu. Poznają nieskomplikowane przepisy na zupę jarzynową, chleb, czekoladowe torciki, krem z bitej śmietanki i słodkie „rogaliki serdeczniki".

\section{Smaczne przekąski Mikolajka}

Marką rozpoznawalną na globalnym rynku mediów dla dzieci jest Mikołajek, którego postać stworzyli Francuzi: humorysta René Goscinny i rysownik Jean-Jacques Sempé. Niesforny protagonista cyklu książeczek, serialu i kilku filmów doczekał się jak dotąd dwóch poradników kulinarnych. Są to Przepisy Mikołajka ${ }^{39}$ oraz Mikołajek $i$ słodkie przekąski ${ }^{40}$, które w Polsce ukazały się nakładem Wydawnictwa „Znak”. Książka opracowana przez Christine de Beaupuré i Béatricé Valentin jest zbiorem pięćdziesięciu — jak zaznaczono w podtytule — „wyjątkowych receptur" na dania spożywane przez bohaterów występujących w opowieściach o Mikołajku. Zostali oni przedstawieni na rozkładówce książki, na której umieszczono wizerunki postaci wraz z imionami. Przepisy zostały podzielone na pięć proporcjonalnych rozdziałów: Pyszne przekaski, Niesamowicie smaczne dania, Fantastyczne desery, Śmieszne pomysty na piknik i Niesamowite smakołyki. Każdy z nich zawiera po dziesięć receptur o wdzięcznych, nierzadko tajemniczych nazwach, jak „,iasto z ciągutkami”, „ryba w papilotach”, „szalone szaszłyki”, „trzypiętrowa kanapka”, „,kurczak w skorupce” czy „zupa z cukinii z Krówką Śmieszką", i równie komicznych opisach. Niektóre z omówień zachęcają dzieci do próbowania nowych smaków (na przykład sera z farszu do pierogów). Inne prezentują nowe techniki kulinarne, zastosowanie rzadkich składników czy nietypowych

38 Ibidem, s. 13.

39 Zob. R. Goscinny, Przepisy Mikołajka: 50 wyjątkowych przepisów, przeł. M. Talar, M. Grzegorzewska, Kraków 2011.

40 Zob. A. Ducasse, Mikołajek i stodkie przekaski, przeł. B. Grzegorzewska, M. Talar, Kraków 2016. 
akcesoriów kuchennych, na przykład ryba w papilotach to ryba pieczona w papierowym „papilocie”. Przepisy uzupełniają takie informacje, jak lista potrzebnych składników i sprzętu kuchennego, liczba porcji, opis przygotowania, cenne uwagi i porady. Wydawca przewidział też miejsce na przypiski do przepisu, czyli dziecięce zapiski. Ilustracje potraw zastąpiono rysunkami i humorystycznymi cytatami z książek o przygodach Mikołajka i jego przyjaciół. Receptury wymagające wsparcia dorosłych zostały adekwatnie oznaczone. Na końcu każdego rozdziału pozostawiono wolną kartkę przeznaczoną na wpisanie własnej receptury.

Mikołajek $i$ słodkie przekaski to książka opracowana przez francuskiego kucharza Alaina Ducasse'a, zdobywcy gwiazdek Michelina, właściciela sieci restauracji na całym świecie, w tym zlokalizowanej na wieży Eiffla. Jako autor książki kucharskiej dla dzieci występuje w roli kulinarnego eksperta, który swoim nazwiskiem i biografią gwarantuje jakość treściową i artystyczną publikacji. Książka obejmuje trzydzieści przepisów na ciasta i słodkości „dla małych i dużych łasuchów", które zostały podzielone na siedem części: Smakowite śniadania (na przykład pancakes, brioszki maślane, croissanty), Na przerwę w szkole (na przykład zdrowe ciasteczka, ,kocie oczka z marmoladą”), Wszystkiego najlepszego! (na przykład tarta z białym serem, tort czekoladowy), Podwieczorek z kumplami (na przykład szybkie lody malinowe, naleśniki, marmurek), Świateczne przepisy (na przykład rolada bożonarodzeniowa wiśniowo-waniliowa, chlebek korzenny), Słodkości dla grzecznych dzieci (na przykład biszkopt, magdalenki cytrynowe), Niedzielne ciasta (na przykład tarta z jabłkami, brownie). Na początku tomu zamieszczono uwagi dla rodziców, którzy mają być przewodnikami dzieci w świecie kulinariów, rady dla „małego szefa kuchni” na temat zasad bezpieczeństwa przy gotowaniu i opis „szuflady z narzędziami wielkich cukierników”. Do książki dołączono alfabetyczny Indeks produktów przydatnych przy pieczeniu.

\section{Nastolatki gotują z Violettą}

W 2014 roku Wydawnictwo „Zielona Sowa” opublikowało trzy poradniki kucharskie adresowane do nastoletnich fanów argentyńskiego serialu Violetta, stworzonego przez Pol-ka Producciones we współpracy z oddziałami Disney Channel, którego światowa premiera odbyła się w 2012 roku. Są to: Violetta. Ksiązka kucharska, Violetta. Jak przygotować udane przyjęcie oraz Violetta. Pomysty na udane przyjęcia ${ }^{41}$. Edycja książek powiązanych z nastolatką obdarzoną niezwykłym talentem wokalnym, łączy się z emisją włoskiego miniserialu $B l o g$ kulinarny Angie (2014), w którym w rolę gospodyń wcieliły się Clara Alonso jako ciocia Angie oraz Mirta Wons jako wspierająca ją w gotowaniu Olga.

41 Zob. A. de Tommassi et al., Violetta. Ksią̇ka kucharska, Warszawa 2014; eidem, Violetta. Jak przygotować udane przyjęcie krok po kroku, Warszawa 2014; eidem, Violetta. Pomysty na udane przyjęcia, Warszawa 2014. 
Poradniki kucharskie Violetty oferują sprawdzone w telewizyjnym show przepisy. Za ich pośrednictwem miłośniczki serialu mogą dowiedzieć się, jak przygotować przyjęcie-niespodziankę, pidżama party, wieczór filmowy, walentynki, piknikowe szaleństwo, garden party, fiestę, a nawet, jak trafić „przez żołądek do serca" ukochanego chłopaka. Opisom okolicznościowych imprez towarzyszą instrukcje, dotyczące dekorowania stołu i pomieszczenia stosownie do okazji, wykonania zaproszenia dla gości, a także propozycje tematycznego menu wraz z przepisami. Na filmowe spotkanie z przyjaciółmi polecane są zatem serowe serca, serduszka z jajek, lukrowe ciasteczka, przekąski-nutki i pomidorowe tulipany. Z kolei na plenerowy piknik — meksykańskie fajitas, guacamole, sałatka caprese i kuleczki serowe. „Jedzeniowy zawrót głowy” stał się tematem zeszytu Jak przygotować przyjęcie krok po kroku. Zaprezentowano tu tematyczne menu między innymi włoskie i owocowe. To drugie obejmuje na przykład sałatkę owocową podaną $\mathrm{w}$ wydrążonej połówce arbuza, tort owocowy, fioletowe galaretki z czarnymi porzeczkami, czekoladowe fondue z owocami na patyczkach, koktajle owocowe, łańcuchy $\mathrm{z}$ winogron $\mathrm{i}$ inne.

Do współtworzenia książek zostały zaproszone fanki Violetty: na blogu violetta-martinastoesselpl.blogspot.co.uk ${ }^{42}$ ogłoszono konkurs na najlepszy i najciekawszy przepis inspirowany serialem. Wyróżnione projekty wydrukowano w poradniku Jak przygotować udane przyjęcie. Aktywna postawa fanów zajmujących się intensywnie tworzeniem rozmaitych tekstów i dyskutowaniem jest reakcją na pojawienie się na rynku oryginalnego produktu, a jednocześnie przejawem praktyki kulturowej, polegającej na „zagarnianiu” i swoistej celebracji wytworów popkultury ${ }^{43}$.

\section{Kulinarne gadżety, interaktywność, wizualność... - o przyjemności płynącej z książek kucharskich dla dzieci}

Progresji książek kucharskich dla dzieci towarzyszy rozwój przemysłu zabawkarskiego. Na globalnym rynku działają wyspecjalizowane firmy produkujące kuchenne bibeloty przeznaczone do zabawy. Wśród nich można znaleźć między innymi kuchenne chodziki z miniaturami sprzętu kuchennego, kuchenki-zabawki do gotowania i całe kąciki kuchenne marki French Cocotte czy Smoby; małe elementy nakrycia i dekoracji stołu, drewniane lub gumowe warzywa i owoce przeznaczone do nauki krojenia czy imitacje konkretnych produktów spożywczych (na przykład szmaciane lody, drewniane kanapki, gumowa pizza niemie-

42 Zawartość bloga usunięta (stan na 1 lipca 2018 roku).

43 J. Storey, Kultura fanów, [w:] idem, Studia kulturowe i badania kultury popularnej. Teorie i metody, przeł. J. Barański, Kraków 2003, s. 116. 
ckiej firmy Erzi), rozmaite akcesoria do pieczenia i gotowania itp. Alan Bryman uznaje sprzedaż gadżetów za jeden z podstawowych wyznaczników „disneizacji kultury” "44. Wytwarzane niejako „niezależnie i obok” produktów medialnych drobiazgi, tworzą wszechobecne otoczenie kulturowe najmłodszych konsumentów. Powodują, że produkty przekraczają granice kultury symbolicznej, stając się nośnikami wartości specyficznych dla kultury materialnej.

Swój rynkowy sukces książki kucharskie dla dzieci niewątpliwie zawdzięczają realizacji funkcji ludycznej, której fundament tworzy motywacja zabawowa. U jej źródeł leży przyjemność połączona z wypełnieniem wolnego czasu i odpoczynkiem. „Zabawowość” — immanentny składnik wszelkich tekstów adresowanych dla młodych konsumentów zaspokaja naturalną u dziecka potrzebę zabawy, która jest nie tylko funkcją kulturową, lecz także biologiczną. W przypadku książki kucharskiej dla najmłodszych związek ten jest o tyle wyraźny, że ma swe umocowanie proweniencyjne. Wszak ten nurt piśmiennictwa dla dzieci wywodzi się wprost z tradycji zabawy w kuchnię i gotowanie. Najwcześniejsze egzemplarze książek kucharskich intencjonalnie skierowanych do „małych kucharzy” wydawane były jako swoiste dodatki do miniaturowych kuchenek do gotowania dla lalek, które rozpowszechniły się w Europie i USA od połowy XIX wieku ${ }^{45}$.

Omawiana kategoria książek funkcjonuje na rynku jako produkt rodzinny, mając walory silnie integrujące domowników: angażuje „do zabawy w gotowanie" najmłodszych, starsze rodzeństwo i dorosłych opiekunów. Pełni tym samym funkcję więziotwórczą: spoiwa umożliwiającego nawiązywanie lub wzmacnianie relacji między członkami familii. Sensowniejsze i przynoszące większy pożytek jest korzystanie $\mathrm{z}$ takiej książki w zespole przynajmniej dwóch osób, $\mathrm{z}$ których jedna zna „kod kulinarny”, a druga tego kodu dopiero się uczy. Ich właściwym i ważniejszym adresatem jest jednak uczący się i z myślą o nim, o jego przyjemności oraz rozwoju kompetencji kulinarnych książki te powstają.

Eliza T. Dresang, pisząc w eseju Radical Change o cechach nowoczesnych — to jest odpowiadających gustom i potrzebom członków net generacji - edycji książek, wskazała między innymi interaktywność (możliwość czynnego odbioru połączona z kreatywnością), intermedialność (włączenie w mozaikę medialną, z której korzysta młodzież - filmy, nagrania muzyczne, zasoby internetu), nielinearność (cecha charakterystyczna dla hipertekstowej natury stron WWW), wysoką atrakcyjność wizualną (odpowiadanie na zwiększone wymagania wykształcone przez media elektroniczne $)^{46}$.

44 A. Bryman, The Disneyization of Society. The Editorial Board of the Sociological Review, „The Sociological Review” 47, 1999, nr 1, s. 57.

45 Zob. A. Has-Tokarz, Od zabawy w gotowanie do ksiażeczek „dla matych kucharzy” — o proweniencji pierwszych ksiązek kucharskich dla dzieci (prolegomena), [w:] O literaturze i kulturze (nie tylko) popularnej, red. A. Gemra, A. Mazurkiewicz, Łódź 2017, s. 181-195.

46 E.T. Dresang, Radical Change, Book for Youth in a Digital Age, New York 1999. 
Książki z omawianej kategorii niewątpliwie spełniają powyższe własności. Ich interaktywność realizuje się de facto na dwóch poziomach: „zewnątrztekstowym" - który manifestuje się poprzez rozmaite aktywności kulinarne, czyli akcesoria dodawane do książek, będące narzędziem budowania dodatkowego zaangażowania w tekst — oraz ,wewnątrztekstowym”. Zawierają one wiele aktywności, jak: rady, gry, łamigłówki, naklejki, szablony, wzory zaproszeń i certyfikatów/dyplomów „małych szefów kuchni”. Interaktywność książek kucharskich dla dzieci projektuje reakcje/decyzje młodego odbiorcy do przetwarzania czy projektowania nowych pomysłów kulinarnych, przyczyniając się de facto do rozwoju jego kreatywności w zakresie gotowania.

W wielu publikacjach zaprojektowano miejsca na rysunki i zapiski własnych przepisów czy menu. Są to przejawy interaktywności rozumianej jako idea akcji i kontrakcji: uczestnicy aktu komunikacji wpływają na siebie wzajemnie, co doprowadza do zmiany struktury tekstu ${ }^{47}$. Czytelnicy mają też możliwość personalizowania egzemplarzy: wydawcy przewidzieli specjalne miejsce na wpisanie imienia i nazwiska właściciela, na przykład „Ta książka należy do...”, „Moja pierwsza książka kucharska" itp. Dzięki tym rozwiązaniom stają się one osobistymi przepiśnikami. Niewątpliwie jest to taktyka marketingowa, odwołująca się z jednej strony do dziecięcej pasji kolekcjonowania, z drugiej — strategii zwanej „efektem lustra”, która opiera się na naśladownictwie ról dorosłych (na przykład umiejscowienie dzieci w samym środku marzenia o byciu dobrą mamą/żona/gospodynią czy popularną gwiazdą telewizyjną ${ }^{48}$. Wzmacnia to rynkowe zainteresowanie publikacjami tego rodzaju.

Współczesne książki kucharskie dla dzieci są w wysokim stopniu wizualne, bardziej przeznaczone „do oglądania”. Postrzega się je jako „towar sprzedażowy, rynkowy, który ze względów kupieckich należy oblepić brokatem, upudrować i polać wiadrem lakieru" - pisze Grzegorz Leszczyński w odniesieniu do publikacji spod znaku Walta Disneya ${ }^{49}$. Zwracają przy tym uwagę rozmaitością stosowanych rozwiązań graficznych i ornamentowych o charakterze stricte dekoracyjnym, barwnych fotografii. Stają się przez to bardziej obrazowe niż edycje wydawane wcześniej, a tekst z przepisem coraz częściej odgrywa w nich służebną rolę w stosunku do obrazu. $Z$ tego względu przestają być wyłącznie źródłem informacji przydatnych w kuchni - są kupowane także w celu zaznajomienia się z przepisami na potrawy, których użytkownicy nie mają zamiaru przygotowywać.

„Obrazowość” współczesnych książek kucharskich dla dzieci ma związek z rozwojem technologii graficznych, które gwarantującą wysoką jakość warsztatu ilustratorskiego, ale przede wszystkim z kształtowaniem się pod wpływem przekazu audiowizualnego nowego kodu kulturowego, którego wyznacznikiem stał

47 M. Hopfinger, Kultura audiowizualna u progu XXI wieku, Warszawa 1997, s. 27.

48 M. Lindstrom, Dziecko reklamy, przeł. A.M. Kawalec, Warszawa 2005, s. 64-68.

49 G. Leszczyński, Literatura i książka dziecięca. Słowo - obiegi - konteksty, Warszawa 2003, s, 81 . 
się obraz, uzależniający najmłodszego odbiorcę od bodźców wizualnych. Dalekie od swej pierwotnej funkcji użytkowej są zwłaszcza albumowe wydania książek kucharskich dla dzieci, tak zwane estetycznie pięknych, odgrywających bardzo często rolę „książek-prezentów" ${ }^{50}$. Te częściej niźli w kuchni znajdują miejsce w salonie. Jako przykład mogą posłużyć Mały Książę: moje domowe ciasteczka ${ }^{51}$ - limitowana edycja w metalowej puszce z foremkami do wypieków — oraz Gratka dla małego niejadka ${ }^{52}$. Podczas czwartej edycji prestiżowego Konkursu CJ Picture Book Awards w Korei wybrano ją do Katalogu 100 najpiękniejszych książek świata.

Rozważając fenomen rynkowej popularności książek kucharskich dla dzieci, należy podkreślić realizowanie przez nie potrzeb przyjemnościowych najmłodszych odbiorców/konsumentów popkultury. Przy czym mamy w tym wypadku do czynienia z przyjemnością „,kodowaną podwójnie”. Z jednej strony — wizualną, związaną z doznaniami natury estetycznej występującymi podczas oglądania, a nierzadko także wąchania książek kucharskich. Z drugiej — płynącą z zabawy w kuchnię i gotowanie, czego wymierne świadectwo stanowią warsztaty kulinarne $\mathrm{z}$ udziałem dzieci oraz konkursy towarzyszące wydawniczym projektom Małgorzaty Musierowicz czy Joanny Krzyżanek. Zabawa „w gotowanie” ma przy tym istotne walory edukacyjne — przy okazji dokonuje się bowiem alfabetyzacja kulinarna dziecięcych konsumentów kultury.

Książki kucharskie stanowią element poszerzający systemy rozrywki dla dzieci, pełniąc funkcje nie tylko użytkowe. Są swoistym odbiciem przemian życia społecznego, a dzięki obecnym w nim mechanizmom oddziaływania perswazyjnego, aktywnie wpływają na kształtowanie się jego ważnych przejawów. Do życia zbiorowego społeczeństwa i prywatnego życia jednostek przenikają z tej kategorii publikacji wzory konsumpcyjne, które kształtują mody związane z nowoczesną sztuką kulinarną.

\section{Bibliografia}

\section{Teksty}

Auta. Jak przygotować przyjęcie krok po kroku. Pomysty na menu, zabawy. Dekoracje, Zielona Sowa, Warszawa 2014.

Capria C., Martucci M., Sprawa konkursu ciast, przeł. N. Mętrak-Ruda, Grupa Wydawnicza „Foksal", Warszawa 2014.

50 Zob. M. Komza, Książki-podarki. Historia, typologia, funkcje, „Studia o Książce” 19, 1993, s. 75-112.

51 Zob. Mały Książę: moje domowe ciasteczka. 50 wyśmienitych przepisów, przeł. A. Ostrowska, Ożarów Mazowiecki 2012.

52 Zob. E. Dziubak, Gratka dla małego niejadka, Poznań 2011. 
Capria C., Martucci M., Sprawa skradzionego roweru, przeł. N. Mętrak-Ruda, Grupa Wydawnicza „Foksal”, Warszawa 2013.

Capria C., Martucci M., Sprawa zaginionego psa, przeł. N. Mętrak-Ruda, Grupa Wydawnicza „Foksal", Warszawa 2014.

Capria C., Martucci M., Sprawa złotego widelca, przeł. N. Mętrak-Ruda, Grupa Wydawnicza „Foksal", Warszawa 2013.

Colson H., Kuchnia Martynki. Najlepsze przepisy zilustrowane krok po kroku, il. N. Charlet, przeł. E. Łukaszczyk, Papilon-Publicat, Poznań 2009.

Davis J., Mam natchnienie na jedzenie. Książka kucharska Garfielda, przepisy B. Albright, przeł. A. Niedźwiecka, Egmont Polska, Warszawa 2005.

Delahaye G., Martier M., Martynka i 40 kuchcików, oprac. W. Chotomska, Papilon, Poznań 2008.

Delahaye G., Martier M., Martynka w kuchni, oprac. W. Chotomska, Publicat, Poznań 2001.

Ducasse A., Mikołajek $i$ słodkie przekaski, przeł. B. Grzegorzewska, M. Talar, Wydawnictwo „Znak”, Kraków 2016.

Dziubak E., Gratka dla matego niejadka, Wydawnictwo „Albus”, Poznań 2011.

Gotuj razem z Tiana: przepisy dla dzieci, przekł. i adaptacja przepisów Z. Naczyńska, Egmont Spółka z o.o., Warszawa 2011.

Gotujemy! Pszczółka Maja, na podst. opowiadań W. Bonselsa, przeł. M. Szpak, Wydawnictwo Olesiejuk, Ożarów Mazowiecki 2008.

Ksią̇ka kucharska Kaczora Donalda, przeł. J. Tarsała, Egmont Polska, Warszawa 1995.

Ksiązka kucharska Kubusia Puchatka, przeł. M.A. Jaworski, Egmont American, Warszawa 1991.

Księżniczki. Jak przygotować przyjęcie krok po kroku. Pomysty na menu, zabawy. Dekoracje, Zielona Sowa, Warszawa 2014.

Kubuś i przyjaciele. Jak przygotować przyjęcie krok po kroku. Pomysty na menu, zabawy. Dekoracje, Wydawnictwo „Zielona Sowa”, Warszawa 2014.

Kubuś Puchatek zaprasza na ciasteczka wg A.A. Milne'a, cytaty z książek przeł. I. Tuwim, przepisy przeł. A. Semkowicz, il. E.H. Shepard, Prószyński i S-ka, Warszawa 1999.

Kubuś Puchatek zaprasza na podwieczorek i mate Conieco: tekst inspirowany „Kubusiem Puchatkiem ” $i$,Chatka Puchatka” A.A. Milne'a, cytaty z książek w przeł. I. Tuwim, przepisy przeł. A. Semkowicz, il. E.H. Shepard, Prószyński i S-ka, Warszawa 1999.

Kubuś Puchatek. Zaproszenie na herbatke, wiersze N. Usenko, oprac. graf. G. Janecka, Egmont Polska, Warszawa 2010.

Kubuś zaprasza na piknik [wg A.A. Milne'a], cytaty z książek przeł. I. Tuwim, przepisy przeł. A. Semkowicz, il. E.H. Shepard, Prószyński i S-ka, Warszawa 1999.

Mały Książę: moje domowe ciasteczka. 50 wyśmienitych przepisów, przeł. A. Ostrowska, Wydawnictwo Olesiejuk, Ożarów Mazowiecki 2012.

McNamara M., Ratatuj. Tak wielu kucharzy, il. N. Wragg, przeł. Z. Naczyńska, Egmont Polska, Warszawa 2007.

McNamara M., Ratatuj. Tak wielu kucharzy, il. N. Wragg, przeł. Z. Naczyńska, Egmont Polska, Warszawa 2007.

Naczyńska Z., Do stotu!, Egmont Polska, Warszawa 2011.

Oworuszko M., Walenty i spótka. Kryminat dietetyczny, Mobuki, Warszawa 2015.

Oworuszko M., Walenty i spótka buduja piramidę, Mobuki, Warszawa 2015.

Oworuszko M., Walenty i spótka podróżują w czasie, Mobuki, Warszawa 2017.

Oworuszko M., Walenty i spółka ruszają w świat, Mobuki, Warszawa 2015.

Oworuszko M., Walenty i spółka szukają witamin, Mobuki, Warszawa 2016.

Ratatuj. Gotuj razem z Gusteau: ksiązka kucharska dla dzieci, przeł. Z. Naczyńska, Egmont Polska, Warszawa 2008.

Goscinny R., Przepisy Mikołajka: 50 wyjątkowych przepisów, przeł. M. Talar, B. Grzegorzewska, Wydawnictwo „Znak”, Kraków 2011. 
Samoloty 2. Jak przygotować przyjęcie krok po kroku. Pomysty na menu, zabawy. Dekoracje, Wydawnictwo „Zielona Sowa”, Warszawa 2014.

Tommasi A. de et al., Violetta. Książka kucharska, Wydawnictwo „Zielona Sowa”, Warszawa 2014.

Tommassi A. de et al., Violetta. Pomysty na udane przyjęcia, Wydawnictwo „Zielona Sowa”, Warszawa 2014.

Tommassi A. de et al., Violetta. Jak przygotować udane przyjęcie krok po kroku, Wydawnictwo „Zielona Sowa”, Warszawa 2014.

Usenko N., Przysmaki, Egmont Polska, Warszawa 2013.

Usenko N., Smakołyki, Egmont Polska, Warszawa 2013.

Wróżki. Jak przygotować przyjęcie krok po kroku. Pomysty na menu, zabawy. Dekoracje, Wydawnictwo „Zielona Sowa”, Warszawa 2014.

\section{Opracowania}

Barber B.R., Skonsumowani. Jak rynek psuje dzieci, infantylizuje dorostych i potyka obywateli, przeł. H. Jankowska, Muza, Warszawa 2009.

Baudrillard J., Społeczeństwo konsumpcyjne - jego mity i struktury, przeł. S. Królak, Wydawnictwo „Sic!”, Warszawa 2006.

Bryman A., The Disneyization of Society. The Editorial Board of the Sociological Review, „The Sociological Review" 47, 1999, nr 1, s. 25-47.

Capodagli B., Jackson L., Metoda Disney'a. Jak skutecznie wykorzystać tajemnice zarządzania Disney'a w twojej firmie, przeł. M. Rusiński, K.E. Lieber, Warszawa 2002.

Cieślikowski J., Literatura i podkultura dziecięca, Ossolineum, Wrocław 1974.

Dresang E.T., Radical Change, Book for Youth in a Digital Age, H.W. Wilson Company, New York 1999.

Has-Tokarz A., Od zabawy w gotowanie do ksiażeczek „, dla małych kucharzy” - o proweniencji pierwszych ksiażek kucharskich dla dzieci (prolegomena), [w:] O literaturze i kulturze (nie tylko) popularnej, red. A. Gemra, A. Mazurkiewicz, Wydawnictwo Uniwersytetu Łódzkiego, Łódź 2017, s. 181-195.

Has-Tokarz A., Bajty do zjedzenia — książki kucharskie dla dzieci w przestrzeni (nowych?) mediów, referat wygłoszony podczas konferencji naukowej Kultura ksiązki w humanistyce współczesnej, 23-24 listopada 2016, Wrocław [mps].

Has-Tokarz A., Kulinarne rymowanki... - o wierszowanych ksiażkach kucharskich dla dzieci (w perspektywie bibliologicznej), referat wygłoszony podczas konferencji naukowej Kuchnia i stót w komunikacji społecznej. Tekst - Dyskurs - Kultura, 15-18 października 2015, Wroclaw $[\mathrm{mps}]$.

Hopfinger M., Kultura audiowizualna u progu XXI wieku, Wydawnictwo IBL PAN, Warszawa 1997.

Jenkins H., Kultura konwergencji. Zderzenie starych i nowych mediów, przeł. M. Bernatowicz, M Filiciak, Wydawnictwo Akademickie i Profesjonalne, Warszawa 2007.

Kinder M., Playing with Power in Movies, Television, and Video Games: From Muppet Babies to Teenage Mutant Ninja Turtles, University of California Press, Berkeley 1991.

Komza M., Książki-podarki. Historia, typologia, funkcje, „Studia o Książce” 19, 1993, s. 75-112.

Kossakowski R., Uprzedmiotowione i „,obrandowane”: dzieci w kulturze towarów, „Teraźniejszość - Człowiek - Edukacja" 2011, nr 1, s. 21-39.

Leszczyński G., Literatura i książka dziecięca. Słowo - obiegi — konteksty, Wydawnictwo CEBID, Warszawa 2003.

Lindstrom M., Dziecko reklamy, przeł. A.M. Kawalec, Świat Książki, Warszawa 2005.

Ritzer G., Magiczny świat konsumpcji, przeł. L. Stawowy, Muza, Warszawa 2001. 
Storey J., Studia kulturowe i badania kultury popularnej: teorie i metody, przeł. i red. J. Barański, Wydawnictwo Uniwersytetu Jagiellońskiego, Kraków 2003.

Zając M., Promocja książki dziecięcej. Podręcznik akademicki, Wydawnictwo SBP, Warszawa 2000.

\title{
Źródla internetowe
}

http://www.gruszkazfartuszka.pl/bajeczne-desery-inspirowane-ksiezniczkami-disneya/ (dostęp: 20.03.2017).

\section{The pleasure of/from consuming... Cookbooks as an element of entertainment systems for children (contexts of consumption culture and media culture)}

\author{
Summary
}

The contemporary market of books for children and teenagers, despite observable short-term periods of decline, is still one of the most stable and profitable segments of the Polish publishing and book market as publishing industry reports show. Publishing houses obtain guaranteed profits first of all from global bestsellers targeted both at the youngest readers and at teenagers. The present article discusses the phenomenon of branding, i.e. the creation of global brands in the sector of books for young readers. Branding has now become an important instrument of international book marketing, while the so-called brand policy occupies a significant position in the marketing tactics of publishers operating in the segment of books for young readers.

The observation of the media in the worldwide and domestic market allows us to see a tendency towards the professionalisation of children's culinary culture. A manifestation of this phenomenon is inter alia the development of the toy industry associated with the manufacture of culinary accessories, as well as the annexation of the media space reserved for children and the young. Within it, we can notice the multiplication of culinary TV programmes, while more and more Internet culinary projects, little chef online games, and applications for mobile devices are becoming available.

A culinary "thematic turn" is also taking place in the book market for children and young people. After 1989, impressive qualitative and quantitative changes took place in the cookbook segment for the youngest readers. This evolution covered their new thematic variants and editorial styles, as well as media formats (culinary audiobooks and e-books), which reflected the global fashions and ideas characteristic of consumer culture, as well as evidenced the culinary emancipation of the youngest. The report will show diverse variants of present-day cookbooks for young readers linked with children's entertainment supersystems. 